\title{
$\mathrm{Zn}$ 계 합금도금재의 미세구조 및 내식성에 미치는 합금 조성 변화 영향 이재원 ${ }^{1} \cdot$ 김성진 $2, *$ · 오민석 ${ }^{3, *}$ \\ ${ }^{1 ㅍ ㅗ ㅎ ㅏ ㅇ ㄱ ㅡ ㅁ ㅅ ㅗ ㄱ ㅅ ㅗ ㅈ ㅐ ㅅ ㅏ ㄴ ㅇ ㅓ ㅂ ㅈ ㅣ ㄴ ㅎ ㅡ ㅇ ㅇ ㅝ ㄴ ~ ㅅ ㅗ ㅈ ㅐ ㅅ ㅗ ㄹ ㄹ ㅜ ㅅ ㅕ ㄴ ㅇ ㅕ ㄴ ㄱ ㅜ ㅅ ㅣ ㄹ ~}$ \\ 2순천대학교 신소재공학과 \\ 3전북대학교 신소재공학부 금속시스템공학과
}

\section{Influence of Alloy Content on Microstructure and Corrosion Resistance of Zn-based Alloy Coated Steel Product}

\author{
Jae-Won Lee ${ }^{1}$, Sung-Jin $\mathrm{Kim}^{2, *}$, and Min-Suk $\mathrm{Oh}^{3, *}$ \\ ${ }^{1}$ Pohang Institute of Metal Industry Advancement (POMIA), Pohang 37666, Republic of Korea \\ ${ }^{2}$ Department of Advanced Materials Engineering, Sunchon National University, Suncheon 57922, Republic of Korea \\ ${ }^{3}$ Department of Metallurgical System Engineering, Jeonbuk National University, Jeonju 54896, Republic of Korea
}

\begin{abstract}
The effects of alloy composition on the coating structure and corrosion resistance of hot-dip Znbased alloy coated steel products were investigated. Zn-based alloy coating layers with different $\mathrm{Al}$ and $\mathrm{Mg}$ compositions were fabricated using a batch-type galvanizing simulator. Various intermetallic compounds including $\mathrm{Zn}, \mathrm{Zn} / \mathrm{MgZn}_{2}$ binary eutectic, $\mathrm{Zn} / \mathrm{Al}$ binary eutectoid and $\mathrm{Zn} / \mathrm{Al} / \mathrm{MgZn}_{2}$ ternary eutectic phases were formed in the coating layer. The surface and cut-edge corrosion resistance of the $\mathrm{Zn}$-based alloy coating were superior to those of the $\mathrm{Zn}$ coating. $\mathrm{Zn}$-based alloy coating containing $15 \% \mathrm{Al}$ and $3 \% \mathrm{Mg}$ showed the best corrosion resistance, with red rust formed on the flat surface after 120 hours in the salt spray test. The corrosion products of the $\mathrm{Zn}$-based alloy coating consisted of Simonkolleite $\left(\mathrm{Zn}_{5}(\mathrm{OH})_{8} \mathrm{Cl}_{2} \cdot \mathrm{H}_{2} \mathrm{O}\right)$, Hydrozincite $\left(\mathrm{Zn}_{5}\left(\mathrm{CO}_{3}\right)_{2}(\mathrm{OH})\right.$ and zinc oxide $(\mathrm{ZnO})$. Al-containing corrosion products, $\mathrm{Zn}_{2} \mathrm{Al}(\mathrm{OH})_{6} \mathrm{Cl}_{2} \cdot \mathrm{H}_{2} \mathrm{O}$ and $\mathrm{Al}_{2} \mathrm{O}_{3}$, were formed when more than $5 \mathrm{wt} \% \mathrm{Al}$ was added. Al-containing corrosion products improved the corrosion resistance of the flat surface of Zn-based alloy coating, but did not affect corrosion resistance in the cut-edge area.
\end{abstract}

(Received July 22, 2019; Accepted January 9, 2020)

Keywords: thin film, surface treatment, wet coating, microstructure

\section{1. 서 론}

아연 도금 강판은 내식성이 우수하여 건축용 자재에서부 터 자동차 부품에 이르기까지 다양한 산업분야에서 널리 사용되고 있다 [1-3]. 지구 온난화가 가속화되면서 청정 에 너지의 효율 증대 기술이 과학 연구 및 개발에서 가장 중 요한 의제로 대두되고 있으며, 도금 산업에서도 재료의 내 식성을 개선하여 자원의 사용량 저감 및 제품의 수명을 연

- 이재원: 연구원, 김성진·오민석: 교수

*Corresponding Author: Sung-Jin Kim

[Tel: +82-61-750-3557, E-mail: sjkim56@sunchon.ac.kr]

*Corresponding Author: Min-Suk Oh

[Tel: +82-63-270-2297, E-mail: misoh@jbnu.ac.kr]

Copyright (c) The Korean Institute of Metals and Materials
장시키는 기술에 대하여 많은 관심을 기울여왔다 [4-6]. 내 식성 향상에 의한 $\mathrm{Zn}$ 도금량 저감은 자원의 보존뿐만 아 니라 생산 비용의 절감효과 또한 크기 때문에 최근 대형 철강사 및 자동차사를 중심으로 $\mathrm{Zn}$ 또는 $\mathrm{Zn}$ 합금에 $\mathrm{Mg}$ 및 $\mathrm{Al}$ 등 이종 합금 원소를 첨가하여 제품의 내식성을 향 상시키는 기술 개발에 대한 연구가 활발히 진행되고 있다 [7-10]. 서로 다른 이종의 금속을 액상으로 혼합하여 도금 할 경우 응고 과정 중에 다양한 금속간 화합물이 형성되므 로, 최적의 내식성 구현을 위해서는 성분에 따른 미세조직 의 거동에 대한 이해와 첨가성분에 대한 비율 최적화가 매 우 중요하다. 특히 $\mathrm{Zn}$ 계 합금도금재의 경우 부식 초기 $\mathrm{MgZn}_{2}$ 상의 우세한 양극반응과 함께 2원계 및 3원계 공 정상에서 부식이 시작되며, 공정 조직의 용해가 완료된 후 
$\mathrm{Zn}$ 단상영역에서 양극반응이 진행된다고 보고되는 등 $\mathrm{Al}$ 및 $\mathrm{Mg}$ 함유 도금재의 부식 거동은 금속간 화합물의 조성 및 형태와 밀접한 관계가 있다고 보고 된 바 있다 [1113]. 따라서 최적의 $\mathrm{Zn}$ 기반 합금 도금 조성 개발을 위해서 는 합금원소의 성분 변화에 따른 금속간 화합물의 미세구조 변화 거동과 부식 성능에 미치는 영향을 파악하는 것이 매 우 중요하다. 본 연구에서는 $\mathrm{Al}$ 및 $\mathrm{Mg}$ 성분변화, 특히 동 일한 $\mathrm{Mg}$ 성분 조건에서 $\mathrm{Al}$ 함유량 변화가 $\mathrm{Zn}$ 계 합금 도금 층의 미세구조 및 내식성에 미치는 영향을 평가하였다.

\section{2. 실험방법}

수직 침지형 용융 아연 도금 모사 장치를 활용하여 서로 다른 조성의 $\mathrm{Al}$ 및 $\mathrm{Mg}$ 을 함유한 $\mathrm{Zn}$ 계 합금 도금 강판을 제조하였다. 하부기판으로 편면에 $60 \mathrm{~g} / \mathrm{m}^{2}$ 의 $\mathrm{Zn}$ 이 도금된 $1.2 \mathrm{~mm}$ 두께의 아연도금강판을 사용하였으며 각각의 시편 을 $30 \times 150 \mathrm{~mm}^{2}$ 로 절단한 후 도금욕에 침지하여 도금하 였다. 도금 수행 전 기판 표면에 잔존하는 불순물 제거를 위해 절단된 시편을 아세톤, 에탄올 및 DI water에 각각 침지 한 후 5 분씩 초음파 처리하였다. 도금욕 온도는 조성 별 용융 온도를 고려하여 $420 \sim 500{ }^{\circ} \mathrm{C}$ 로 조정하였다. 아연 도금 된 기판을 도금욕에 침지 한 후 약 5 초간 진동을 가 하여 기존 아연층을 제거한 후 잔존하는 $\mathrm{Al}-\mathrm{Fe}$ 금속간화 합물층 위에 합금도금층을 형성하였다. 도금 공정은 대기 중에서 이루어졌으며 강판의 이동속도 및 도금욕 내 유지 시간을 조절하여 각 조성별로 편면 기준 $100 \sim 300 \mathrm{~g} / \mathrm{m}^{2}$ 범 위로 도금량을 제어하였다. 강판은 도금 후 대기상태에서 실온으로 냉각되었다. 그림 1에 본 연구에 사용된 Batch형 용융 도금 모사 장치를 도식적으로 나타내었다. 금속의 용 해를 위해 고주파 유도 용해로를 사용하였고, 지정된 크기 로 절단된 시험편을 시편 홀더에 장착한 후 용융 상태의 금속에 침지하여 도금하였으며 Controller를 이용하여 시험 편의 침지 시간 및 도금 속도를 제어하였다. 도금욕 및 도 금층의 조성은 유도결합 플라즈마(ICP) 방법을 사용하여 분석하였으며 그 결과값을 표 1 에 나타내었다. 분석 결과 $\mathrm{A} 3 \mathrm{M} 3$ 는 $3.36 \% \mathrm{Al}-3.1 \% \mathrm{Mg}, \mathrm{A} 5 \mathrm{M} 3$ 는 $5.6 \% \mathrm{Al}-3.23 \% \mathrm{Mg}$ 및 $\mathrm{A} 15 \mathrm{M} 3$ 는 $13.8 \% \mathrm{Al}-3.12 \% \mathrm{Mg}$ 조성을 갖는 도금층이 형성되었다. 주사전자현미경 (FE-SEM, SU6600, Hitachi) 및 전자빔 미세분석법 (EPMA, JXA-8500F, JEOL)을 사 용하여 도금층의 표면 및 단면의 미세구조를 관찰하였다. 도금된 시험편의 내식성 평가를 위해 $35^{\circ} \mathrm{C}$ 에서 $5 \% \mathrm{NaCl}$ 염수를 $1.5 \sim 1.8 \mathrm{ml} / 80 \mathrm{~cm}^{2}$ 으로 분무하는 ASTM B117 규 격에 맞추어 염수분무시험 (Salt spray test, SST, SUGA)

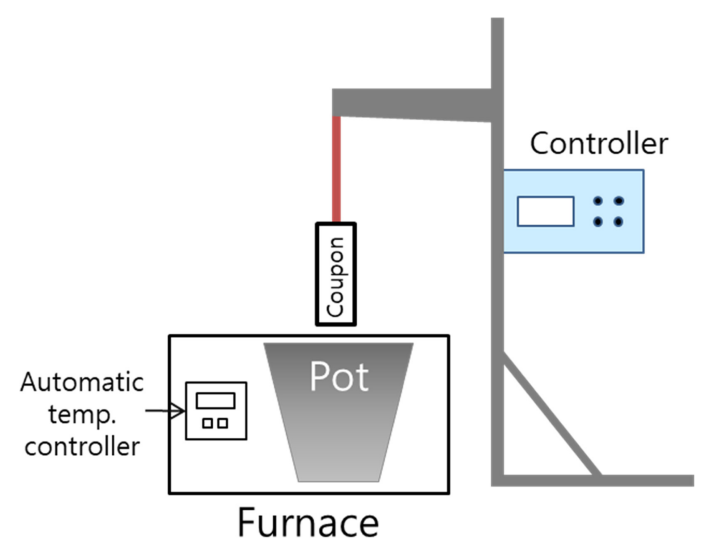

Fig. 1. An illustration of batch-type hot-dip galvanizing simulator.

Table 1. Target and measured bath composition of Zn-based alloy coatings.

\begin{tabular}{ccccccc}
\hline \multirow{2}{*}{ Sample } & \multicolumn{3}{c}{ Target $(\mathrm{wt} \%)$} & \multicolumn{3}{c}{ Result (ICP, wt\%) } \\
\cline { 2 - 7 } & $\mathrm{Al}$ & $\mathrm{Mg}$ & $\mathrm{Zn}$ & $\mathrm{Al}$ & $\mathrm{Mg}$ & $\mathrm{Zn}$ \\
\hline Zn & - & - & 100 & - & - & 100 \\
\hline A3M3 & 3 & 3 & & 3.36 & 3.1 & \\
\hline A5M3 & 5 & 3 & & 5.6 & 3.23 & \\
\hline A15M3 & 15 & 3 & & 13.8 & 3.12 & \\
\hline
\end{tabular}

을 수행하였다 [14]. 부식 반응에 의해 형성된 부식생성물 의 미세구조 및 상 분석은 FE-SEM과 XRD (RINT-2000, Rigaku)를 사용하여 실시하였다.

\section{3. 결과 및 고찰}

\section{1 도금층 외관 및 미세조직}

그림 2(a)-(d)는 서로 다른 조성을 갖는 $\mathrm{Zn}$ 계 합금도금 강재의 외관을 나타낸다. 도금욕 제조 시 용융 $\mathrm{Zn}$ 에 첨가 되는 $\mathrm{Mg}$ 및 $\mathrm{Al}$ 의 함량이 증가함에 따라 도금욕 욕면에 부유하는 고체 드로스가 증가하는 경향을 보였으며 도금욕 욕면에 부유한 고체 드로스가 도금재 표면에 흡착되어 표 면 요철 결함을 유발하였다. 육안 관찰 결과 그림 2에 보 이는 바와 같이 $\mathrm{Al}$ 및 $\mathrm{Mg}$ 가 함유된 합금도금재 중 $\mathrm{A} 3 \mathrm{M} 3$ 시편의 표면 결함이 가장 적었으며 도금욕의 유동성 도 타 조성 대비 높았다. 이는 $\mathrm{A} 3 \mathrm{M} 3$ 조성이 $\mathrm{Zn}$ 계 합금 의 공정 조성에 근접하여 용융점 $\left(336{ }^{\circ} \mathrm{C}\right)$ 이 낮아지기 때 문인 것으로 판단된다. $\mathrm{Mg}$ 대비 $\mathrm{Al}$ 함량이 높은 $\mathrm{A} 15 \mathrm{M} 3$ 조건의 경우 높은 도금욕 온도 $\left(\sim 500{ }^{\circ} \mathrm{C}\right)$ 에서도 상대적으 로 많은 드로스 결함이 발생하였다.

그림 3(a)-(d)는 $\mathrm{Al}$ 과 $\mathrm{Mg}$ 조성 변화에 따른 $\mathrm{Zn}$ 계 합금 도금층의 $\mathrm{FE}-\mathrm{SEM}$ 단면 사진을 나타낸다. 그림에 나타낸 

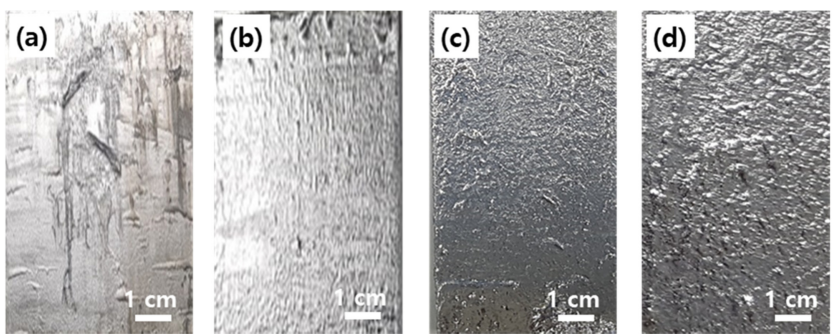

Fig. 2. Images of the $\mathrm{Zn}-\mathrm{Al}-\mathrm{Mg}$ coatings with different $\mathrm{Al}$ and $\mathrm{Mg}$ content; (a) Zn, (b) A3M3, (c) A5M3, and (d) A15M3.
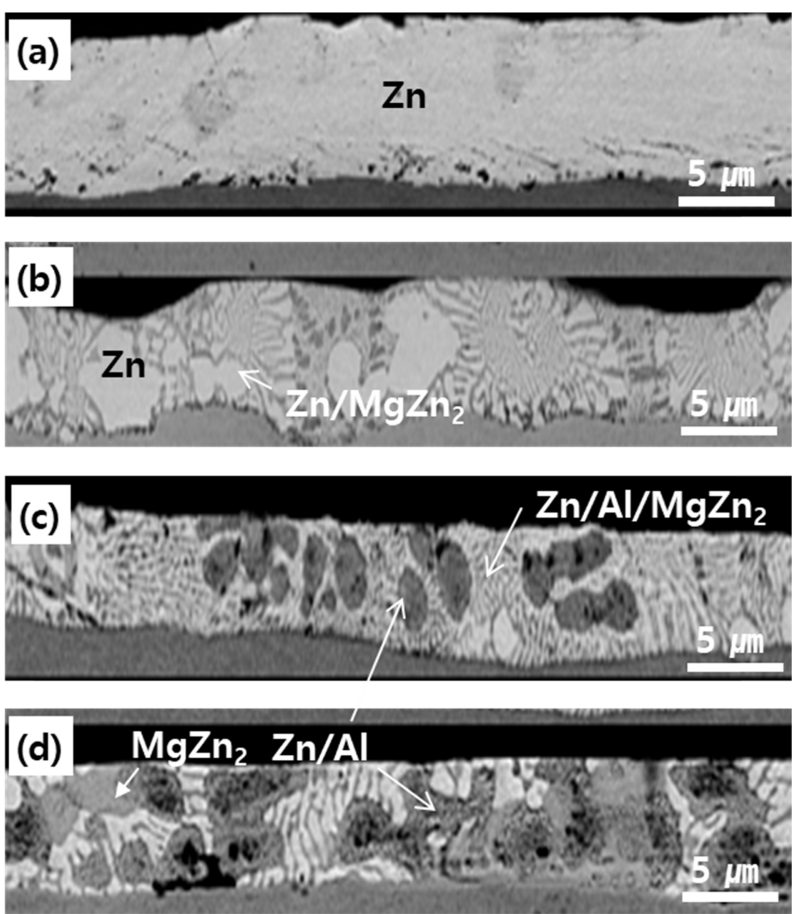

Fig. 3. Cross-sectional images of the $\mathrm{Zn}-\mathrm{Al}-\mathrm{Mg}$ coatings with different $\mathrm{Al}$ and $\mathrm{Mg}$ content; (a) $\mathrm{Zn}$, (b) $\mathrm{A} 3 \mathrm{M} 3$, (c) $\mathrm{A} 5 \mathrm{M} 3$, and (d) A15M3.

바와 같이 $100 \% \mathrm{Zn}$ 으로 이루어진 $\mathrm{Zn}$ 도금층 (그림. 3(a))과 다르게 $\mathrm{Mg}$ 및 $\mathrm{Al}$ 등 이종 금속을 첨가함으로써 $\mathrm{Zn}$ 단상 이외에 $\mathrm{MgZn}_{2}, \mathrm{Zn} / \mathrm{MgZn}_{2}$ 2원 공정상, $\mathrm{Zn} / \mathrm{Al} 2$ 원 공석상 및 $\mathrm{Zn} / \mathrm{Al} / \mathrm{MgZn}_{2}$ 3원 공정상과 같은 다양한 금 속간 화합물이 도금층 내에 형성되었다. $\mathrm{EDS}$ 분석 결과 참고문헌 15 및 16 과 유사하게 $\mathrm{Zn} / \mathrm{MgZn}_{2}$ 2원 공정상은 $100 \% \mathrm{Zn}$ 과 $16.4 \%$ 의 $\mathrm{Mg}$ 을 함유한 $\mathrm{MgZn}_{2}$ 로 구성되었으 며 $\mathrm{Zn} / \mathrm{Al}$ 상에는 $23.4 \%$ 의 $\mathrm{Al}$ 과 $1.23 \%$ 의 $\mathrm{Fe}$ 가 검출되는 결과를 보여주었다 $[15,16] . \mathrm{Al}$ 및 $\mathrm{Mg}$ 함유량이 증가함에 따라 $\mathrm{Zn}$ 단상의 체적비는 감소하였으며 금속간화합물의 면 적은 비례적으로 증가하였다. $\mathrm{A} 3 \mathrm{M} 3$ 도금층의 경우 $\mathrm{Zn}$ 단 상이 존재하였으며 조대 $\mathrm{Zn} / \mathrm{MgZn}_{2}$ 공정상 및 $\mathrm{Zn} / \mathrm{Al} /$
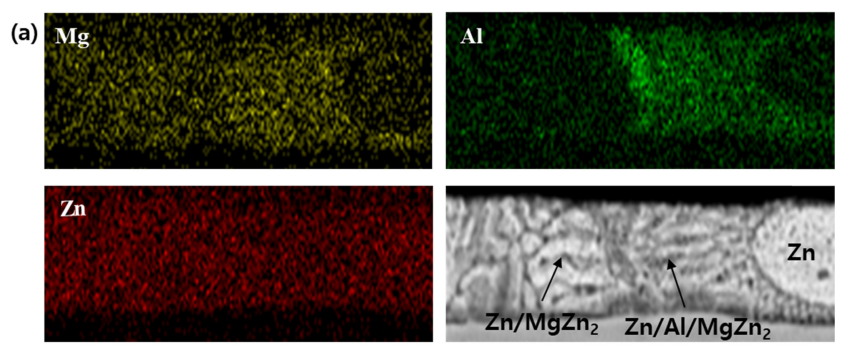

(b) $\mathrm{Mg}$
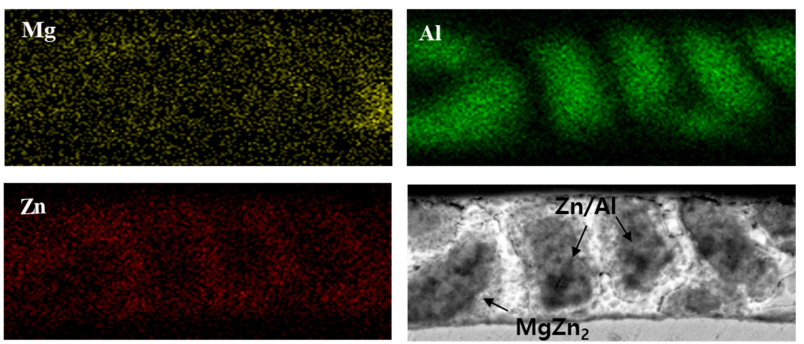

Fig. 4. The element distribution in the $\mathrm{Zn}-\mathrm{Al}-\mathrm{Mg}$ coatings with different $\mathrm{Al}$ and $\mathrm{Mg}$ content; (a) A3M3, (b) A15M3.

$\mathrm{MgZn}_{2}$ 금속간화합물이 균일하게 분포하였다. 그림 3(c)와 (d)에 보이는 바와 같이 동일한 $3 \mathrm{wt} \%$ 의 $\mathrm{Mg}$ 성분 조건에 서 $\mathrm{Al}$ 함유량이 $5 \mathrm{wt} \%$ 이상으로 증가됨에 따라 합금 도 금층 내에 $\mathrm{Zn} / \mathrm{Al}$ 공석상이 형성되었다. 특히 $\mathrm{A} 15 \mathrm{M} 3$ 시편 의 경우 그 경향이 두드러졌으며 $\mathrm{Zn} / \mathrm{Al}$ 공석상 주변에 $\mathrm{MgZn}_{2}$ 금속간화합물이 광범위하게 분포하였다.

$\mathrm{Al}$ 및 $\mathrm{Mg}$ 조성에 따른 도금층 내 성분 분포를 알아보 기 위해 $\mathrm{A} 3 \mathrm{M} 3$ 및 $\mathrm{A} 15 \mathrm{M} 3$ 시편의 단면을 $\mathrm{EPMA}$ 를 활용 하여 측정한 후 각각 그림 4(a) 및 (b)에 나타내었다. $\mathrm{Al}$ 및 $\mathrm{Mg}$ 의 성분 분포를 통해 $\mathrm{A} 3 \mathrm{M} 3$ 도금층은 $\mathrm{Zn}$ 초정과 $\mathrm{Zn} / \mathrm{MgZn}_{2}$ 및 $\mathrm{Zn} / \mathrm{Al} / \mathrm{MgZn}_{2}$ 공정상이 균일하게 분포하는 것을 확인 할 수 있으며 $\mathrm{A} 15 \mathrm{M} 3$ 의 경우 앞서 언급된 바 와 같이 조대 $\mathrm{Zn} / \mathrm{Al}$ 공석상과 $\mathrm{MgZn}_{2}$ 금속간화합물이 광 범위하게 형성되어 있음을 확인 할 수 있다.

\section{2 내식성 평가 결과}

서로 다른 $\mathrm{Al}$ 및 $\mathrm{Mg}$ 조성을 갖는 $\mathrm{Zn}$ 계 합금 도금재의 평판부 내식성 평가를 위해 염수분무시험(SST)을 진행하였 다. 그림 5는 본 연구를 위해 제작된 도금재에 대한 SST 시간 별 적청 발생 거동을 나타낸다. 그림 5에 보이는 바 와 같이, $\mathrm{Al}$ 및 $\mathrm{Mg}$ 가 함유된 모든 합금 도금층의 내식성 은 $\mathrm{Zn}$ 도금재 대비 우수하였으며 $\mathrm{Al}$ 및 $\mathrm{Mg}$ 성분이 증가 할수록 내식성이 향상되는 경향을 보였다. $\mathrm{Zn}$ 도금재의 경 우 SST 평가 8시간 경과 후 도금층 표면에 적청이 발생한 반면 $\mathrm{A} 3 \mathrm{M} 3$ 및 $\mathrm{A} 5 \mathrm{M} 3$ 은 72 시간, $\mathrm{A} 15 \mathrm{M} 3$ 은 120 시간 경과 후 표면 적청이 발생하였다. Image analyzer를 이용 


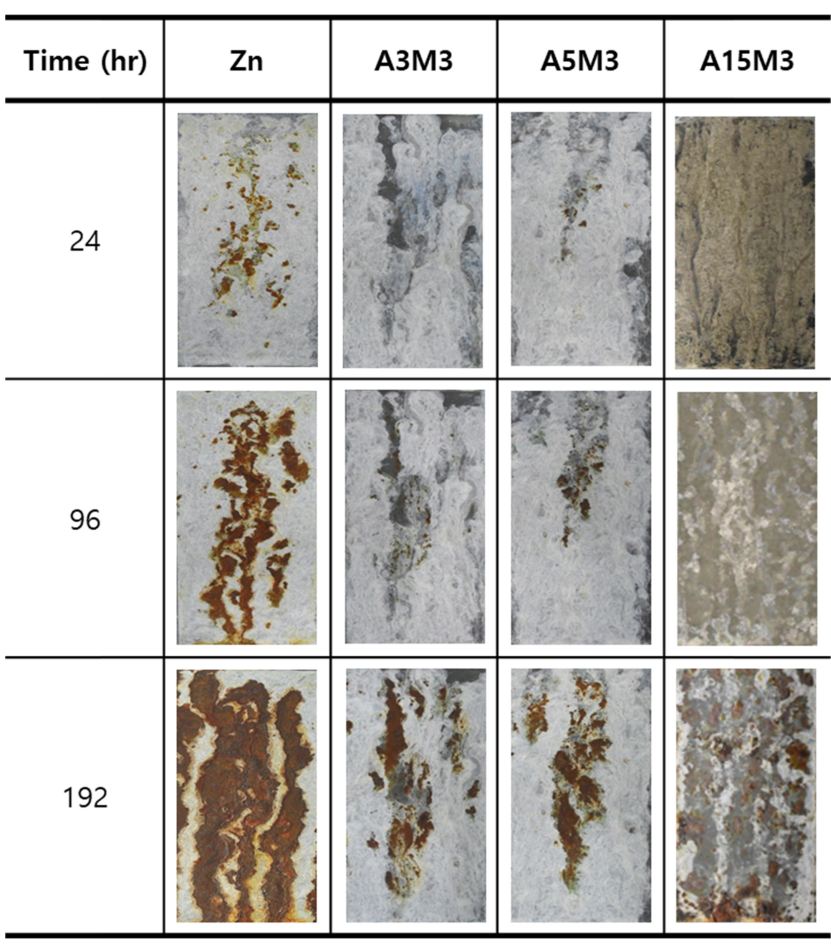

Fig. 5. Red rust formation in $\mathrm{Zn}-\mathrm{Al}-\mathrm{Mg}$ coatings with different $\mathrm{Al}$ and $\mathrm{Mg}$ content as a function of SST time.

하여 각 샘플별로 $5 \%$ 적청 면적 발생 시간을 측정한 결과, $\mathrm{Zn}$ 는 24 시간, $\mathrm{A} 3 \mathrm{M} 3$ 및 $\mathrm{A} 5 \mathrm{M} 3$ 은 120시간, $\mathrm{A} 15 \mathrm{M} 3$ 은 150 시간으로써 $\mathrm{Zn}$ 계 합금 도금제품의 평판부 내식성이 $\mathrm{Zn}$ 도금재 대비 약 5 7 배 높게 평가되었다.

강판을 활용한 대부분의 구조물은 제품생산을 위해 절단 가공을 거치게 되며 따라서 절단면부 내식성은 매우 중요 하다. $\mathrm{Zn}$ 계 합금 도금재의 절단면부 내식성 평가를 위해 $100 \% \mathrm{Zn}, 3 \% \mathrm{Al}-3 \% \mathrm{Mg}, 5 \% \mathrm{Al}-3 \% \mathrm{Mg}$ 및 $15 \% \mathrm{Al}-3 \% \mathrm{Mg}$ 등 각각의 시험편을 절단한 후 SST 평가를 수행하였다. 시편 별 절단면의 동일한 염수 접촉면적 확보를 위해 마운 팅 후 polishing 처리하였다. 그림 6은 다양한 조성을 갖 는 실험재의 절단면부에 대한 SST 시간 별 부식 거동을 나타낸다. 평판부 내식성과 유사하게 $\mathrm{Al}$ 및 $\mathrm{Mg}$ 첨가 도금 재의 절단면부 내식성이 $\mathrm{Zn}$ 코팅재 대비 우수하였다. 그림 6 에 보이는 바와 같이 절단면부의 적청 발생 시간이 평판 부 대비 빨랐으며 이는 절단면부의 경우 강재가 $\mathrm{Zn}$ 코팅 없이 부식성 대기에 직접 노출되기 때문이다. 도금되지 않 은 강재의 노출 부위와 양쪽면에 도금 되어있는 코팅층이 부식분위기에 동시에 노출되는 전단면의 특성상 부식이 진 행됨에 따라 양쪽면 도금층이 용출된 후 강판 노출 부위로 확산되며 확산된 도금층 성분은 산화된 후 안정적인 부식 생성물을 형성시킨다. 이렇게 형성된 치밀한 부식생성물은

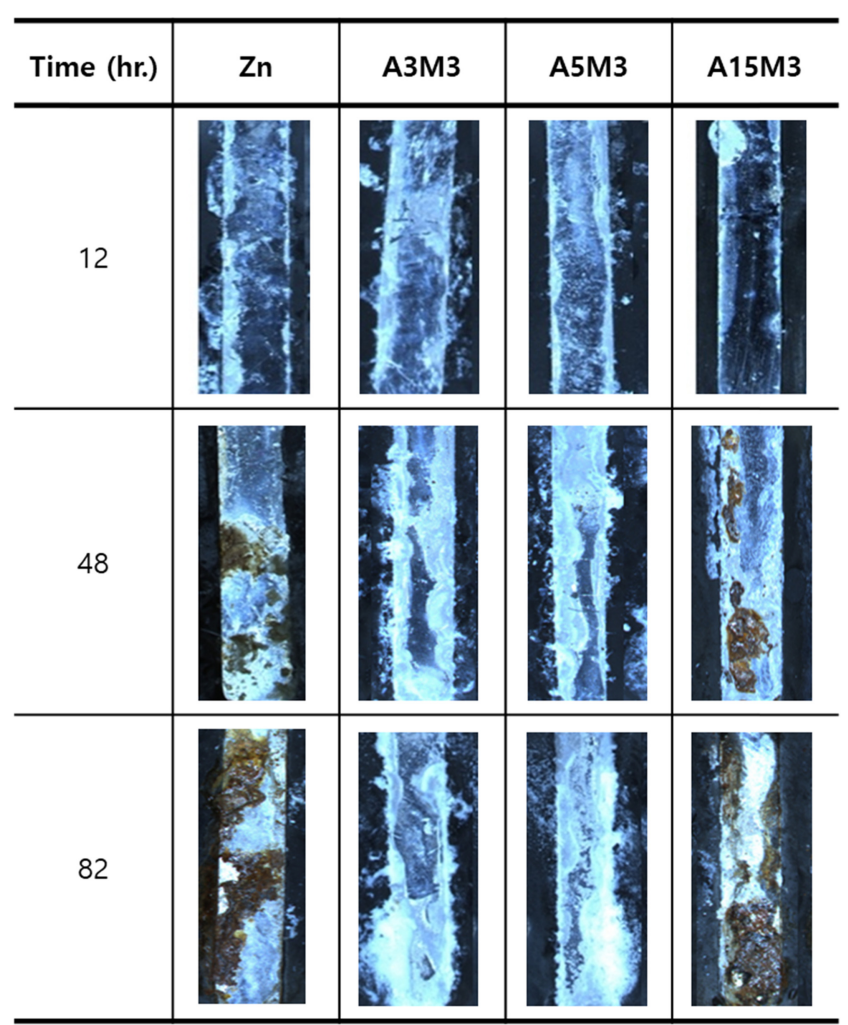

Fig. 6. Red rust formation in the cut-edge area of $\mathrm{Zn}-\mathrm{Al}-\mathrm{Mg}$ coatings with different $\mathrm{Al}$ and $\mathrm{Mg}$ content as a function of SST time.

추가적인 부식 진행을 억제하는 barrier 역할을 수행하여 도금강판의 절단면부 내식성 향상에 기여하는 것으로 판단 된다 [17]. 주목 할 만한 사항으로 매우 우수한 평판부 내 식성을 보인 $\mathrm{A} 15 \mathrm{M} 3$ 샘플의 경우 절단면부의 내식성이 다 른 합금도금재 대비 열위 하였으며 $\mathrm{Zn}$ 도금재와 유사한 전단면부 내식성을 보였다. 성분별 미세조직과 그에 따른 내 식성 평가결과를 토대로 $\mathrm{A} 15 \mathrm{M} 3$ 도금층내에 형성되는 $\mathrm{Zn} /$ $\mathrm{Al}$ 2원 공석상은 평판부 내식성 항상에는 크게 기여하나 절 단면부 내식성 향상에는 기여하지 못함을 유추할 수 있다.

$\mathrm{Al}$ 및 $\mathrm{Mg}$ 조성에 따른 도금층 미세조직과 합금도금재의 평면부 및 전단면부의 내식성 변화에 대한 원인을 알아보 기 위해 도금층 표면에 형성된 부식생성물을 $\mathrm{XRD}$ 를 활용 하여 분석하였다. 그림 7은 SST 96 시간 경과 후 $\mathrm{Zn}$ 계 합 금 도금재의 표면에 형성된 부식 생성물에 대한 XRD 결과 를 나타낸다. $\mathrm{Zn}$ 도금재의 경우 심한 적청 발생으로 분석이 어려웠던 반면 $\mathrm{Zn}$ 계 합금도금재의 경우 Simonkolleite $\left(\mathrm{Zn}_{5}(\mathrm{OH})_{8} \mathrm{Cl}_{2} \cdot \mathrm{H}_{2} \mathrm{O}\right)$, Hydrozincite $\left(\mathrm{Zn}_{5}\left(\mathrm{CO}_{3}\right)_{2}(\mathrm{OH})\right)$ 및 산화 아연 $(\mathrm{ZnO})$ 등의 부식생성물이 다량 검출되었다. 특히 심 한 적청이 발생되기 전(SST 24 시간 경과 후) Zn 도금재 


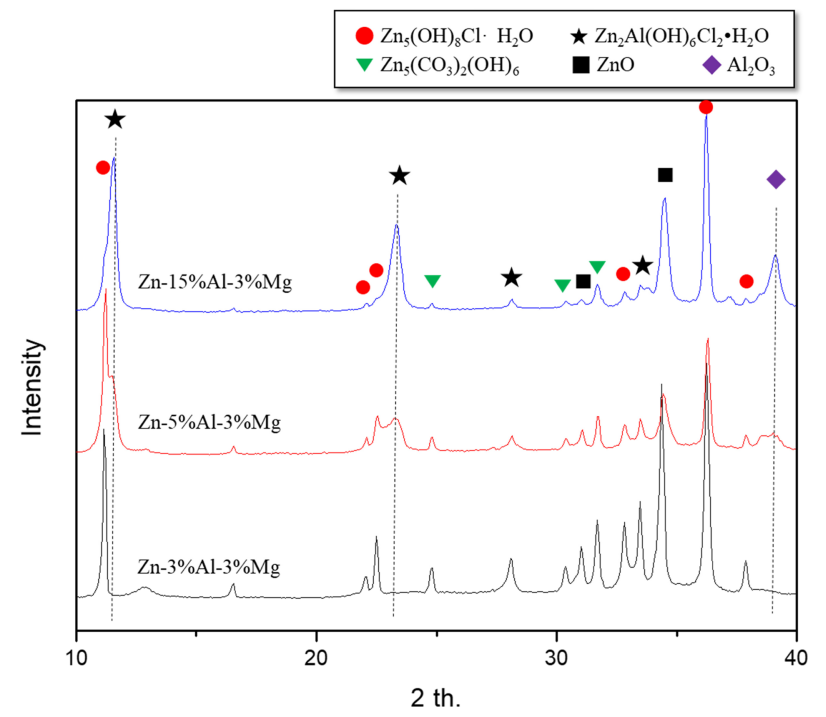

Fig. 7. X-ray diffraction patterns of corrosion products of Zn-Al$\mathrm{Mg}$ with different $\mathrm{Al}$ and $\mathrm{Mg}$ content after 96 hours in SST.

표면에 형성된 부식생성물과 비교 분석한 결과, $\mathrm{Al}$ 및 $\mathrm{Mg}$ 첨가에 의해 Simonkolleite peak의 강도가 매우 증가하는 경향이 관찰되었다. Simonkolleite는 내식성이 우수한 부식 생성물로 알려져 있으며 이러한 고내식 특성을 갖는 부식 생성물의 형성이 합금 첨가에 의해 촉진되는 것으로 판단 된다 $[18,19] .5 \mathrm{wt} \%$ 이상의 $\mathrm{Al}$ 첨가 시 상기 부식 생성 물 이외에 $\mathrm{Al}$ 이 함유된 $\mathrm{Zn}_{2} \mathrm{Al}(\mathrm{OH})_{6} \mathrm{Cl}_{2} \cdot \mathrm{H}_{2} \mathrm{O}$ 및 $\mathrm{Al}_{2} \mathrm{O}_{3}$ 부 식생성물이 분석되었다. 특히 $\mathrm{A} 15 \mathrm{M} 3$ 시편의 경우 $\mathrm{Al}$ 함 유 부식생성물 증가가 두드러졌으며 이는 도금층 내에 형 성된 $\mathrm{Zn} / \mathrm{Al}$ 2원 공석상의 부식에 의해 형성된 생성물로 판단된다. 전단면 내식성 평가 결과 상기 $\mathrm{Al}$ 함유 부식생 성물은 평판부 내식성 증가를 유도하였지만 강판이 노출된 절단면부의 내식성 향상에는 기여하지 못했다.

성분별 미세조직과 그에 따른 내식성 평가결과를 종합하 여 볼 때, $\mathrm{Zn}$ 계 합금도금재는 $\mathrm{Zn} / \mathrm{MgZn}_{2}$ 및 $\mathrm{Zn} / \mathrm{Al} /$ $\mathrm{MgZn}_{2}$ 상에서 용해된 $\mathrm{Mg}^{2+}$ 및 $\mathrm{Al}^{2+}$ 양이온이 도금층 표 면의 음극 영역에서 석출하여 조밀하고 안정한 부식 생성 물(Simonkolleite 등)을 형성함으로써 내식성을 향상시켰으 며 $\mathrm{Al}$ 함량 증가 시 형성되는 $\mathrm{Zn} / \mathrm{Al}$ 공석상은 평판부 내 식성 향상에는 기여하나 절단면부에서 용출되는 도금층의 확산을 억제하여 전단면부 내식성 향상에는 기여하지 못하 는 것으로 사료된다.

\section{4. 결 론}

본 연구에서는 $\mathrm{Al}$ 및 $\mathrm{Mg}$ 조성에 따른 $\mathrm{Zn}$ 계 합금 코팅
층의 미세조직 변화가 합금 도금 강재의 내식성에 미치는 영향을 평가하였다. $\mathrm{Al}$ 및 $\mathrm{Mg}$ 의 첨가로 $\mathrm{Zn}$ 상 이외에 $\mathrm{MgZn}_{2}, \mathrm{Zn} / \mathrm{MgZn}_{2}$ 공정상, $\mathrm{Zn} / \mathrm{Al}$ 공석상 및 $\mathrm{Zn} / \mathrm{Al} / \mathrm{MgZn}_{2}$ 공정상과 같은 다양한 금속간화합물이 형성되었다. $\mathrm{Zn}$ 계 합금 도금층의 평판부 및 단면부 내식성은 $\mathrm{Zn}$ 도금재 대비 우수하였으며 $\mathrm{Al}$ 및 $\mathrm{Mg}$ 성분이 증가할수록 내식성이 향상 되었다. $\mathrm{Zn}$ 계 합금도금재의 부식생성물은 Simonkolleite $\left(\mathrm{Zn}_{5}(\mathrm{OH})_{8} \mathrm{Cl}_{2} \cdot \mathrm{H}_{2} \mathrm{O}\right)$, Hydrozincite $\left(\mathrm{Zn}_{5}\left(\mathrm{CO}_{3}\right)_{2}(\mathrm{OH})\right)$ 및 산 화 아연 $(\mathrm{ZnO})$ 등으로 이루어져 있으며 $5 \mathrm{wt} \%$ 이상의 $\mathrm{Al}$ 첨가 시 $\mathrm{Zn}_{2} \mathrm{Al}(\mathrm{OH})_{6} \mathrm{Cl}_{2} \cdot \mathrm{H}_{2} \mathrm{O}$ 및 $\mathrm{Al}_{2} \mathrm{O}_{3}$ 등 $\mathrm{Al}$ 을 함유 한 부식생성물이 형성되었다. 연구 결과 $\mathrm{Zn}$ 기반 합금도금 재는 $\mathrm{Zn} / \mathrm{MgZn}_{2}$ 및 $\mathrm{Zn} / \mathrm{Al} / \mathrm{MgZn}_{2}$ 등 $\mathrm{Mg}$ 함유 금속간화합 물에서 용출된 $\mathrm{Mg}^{2+}$ 및 $\mathrm{Al}^{2+}$ 양이온이 도금층 표면의 음 극 영역에서 석출한 후 안정적인 부식 생성물을 형성함으 로써 내식성이 향상됨을 알 수 있었다.

\section{ACKNOWLEDGMETNS}

This work was supported by the National Research Foundation of Korea(NRF) grant funded by the Korea government(MSIT) (No. 2019R1A2C1007552) and this paper was also supported by research funds for newly appointed professors of Chonbuk National University in 2018.

\section{REFERENCES}

1. N. Pistofidis, G. Vourlias, S. Konidaris, E. Pavlidou, A. Stergiou, and G. Stergioudis, Mater. Lett. 60, 786 (2006).

2. S. Maeda, Progr. Org. Coating. 28, 227 (1996).

3. G. M. Song, T. Vystavel, N. van der Pers, J. T. M. De Hosson, and W. G. Sloof, Acta Mater. 60, 2973 (2012).

4. N. Pistofidis, G. Vourlias, S. Konidaris, E. Pavlidou, A. Stergiou, and G. Stergioudis, Mater. Lett. 61, 994 (2007).

5. A. Amadeh, B. Pahlevani, and S. Heshmati-Manesh, Corros. Sci. 44, 2321 (2002).

6. W. Trabelsi, E. Triki, L. Dhouibi, M. L. Zheludkevich, and M. F. Montemor, Surf. Coating. Tech. 200, 4240 (2006).

7. S. Schuerz, M. Fleischanderl, G. H. Luckeneder, K. Preis, T. Haunschmied, G. Mori, and A. C. Kneissl, Corros. Sci. 51, 2355 (2009).

8. S. Schürz, G. H. Luckeneder, M. Fleischanderl, P. Mack, H. Gsaller, A. C. Kneissl, and G. Mori, Corros. Sci. 52, 3271 (2010). 
9. K. Honda, W. Yamada, and K. Ushioda, Mater. Trans. 49, 1395 (2008).

10. M. S. Oh, S. H. Kim, J. S. Kim, J. W. Lee, J. H. Shon, and Y. S Jin, Met. Mater. Int. 22, 26 (2016).

11. T. Prosek, A. Nazarov, U. Bexell, D. Thierry, and J. Serak, Corros. Sci. 50, 2216 (2008).

12. O. Lunder, J. E. Lein, T. Kr Aune, and K. Nisancioglu, Corrosion 45, 741 (1989).

13. E. Zhang, D. Yin, L. Xu, L. Yang, and K. Yang, Mater. Sci. Eng. C 29, 987 (2009).

14. ASTM B117-16, Standard Practice for Operating Salt
Spray (Fog) Apparatus, ASTM International (1997).

15. J. Zhang, Z. X. Guo, F. Pan, Z. Li, and X. Luo, Mater. Sci. Eng. 456, 43 (2007).

16. E. De Bruycker, Z. Zermout, and B. C. De Cooman, Mater. Sci. Forum 539, 1276 (2007).

17. C. Liu, A. Leylanda, Q. Bi, and A. Matthews, Surf. Coating. Tech. 141, 164 (2001).

18. N. C. Hosking, M. A. Strom, P. H. Shipway, and C. D. Rudd, Corros. Sci. 49, 3669 (2007).

19. R. Autengruber, G. Luckeneder, and A. W. Hassel, Corros. Sci. 63, 12 (2012). 